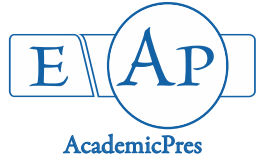

\title{
Hybridization in Four Nigerian Physalis (Linn.) Species
}

\author{
Sekinat Okikiola AZEEZ*, Julius Olaoye FALUYI
}

\author{
Obafemi Awolowo University, Faculty of Science, Department of Botany, \\ Nigeria; sekinatokiki@gmail.com ("corresponding author); jfaluyi@gmail.com
}

\begin{abstract}
Interspecific reciprocal crosses among four Nigerian Physalis species (Physalis angulata, P. micrantha, P. pubescens and P. peruviana) were carried out by transferring desired pollen grains to ovalate parents, bagged and labelled to prevent contamination by external pollen grains and for easy identification. Pollen cells of the $\mathrm{F}_{1}$ hybrid combination from the only viable cross ( $P$. angulata $\mathrm{x} P$. pubescens) were studied using standard cytogenetic techniques. The $\mathrm{F}_{1}$ hybrid obtained in the current investigation produced few flower buds and no matured fruit was harvested. Its average pollen grain diameter was found within the range of that of the two genitors and the pollen stainability was less than $50 \%$. The hybrid was also characterized by meiotic irregularities. Based on the results obtained, the study concluded that $P$. pubescens is closely related to $P$. angulata and $P$. peruviana, while $P$. micrantha is more distant from them since the formal individuals were able to cross reciprocally among each other, though no matured fruit was produced except in one cross ( $P$. angulata $\mathrm{x} P$. pubescens).
\end{abstract}

Keywords: interspecific hybridization; meiotic irregularities; pollen grains

\section{Introduction}

The genus Physalis Linn. species belongs to the night shade family called Solanaceae (Olorode, 1984; Jagatheeswari, 2014). This is a family of herbs, shrubs, rarely small trees, climbers, vines, epiphytes (Olorode, 1984). The genus includes about 100 species (Sultana et al., 2008; ElSheikha et al., 2009) which were divided into three sections: Physalis (Euphysalis), Microphysalis and Megista (Sullivan, 1984). In West Africa, four species ( $P$. angulata L., $P$. micrantha Link., $P$. pubescens L. and $P$. peruviana L.) were reported and all are present in Nigeria (Hutchinson and Dalziel, 1963; Olatunji, 1985). The genus constitutes a natural group of annual and perennial herbs characterised by solitary flowers borne on the axils of leaves and branches (Menzel, 1951; Olatunji, 1985; Shu, 1994).

Olorode et al. (2013) opined that Physalis angulata L. $(2 n=48)$ might be of hybrid origin from a cross between $P$. peruviana $(2 n=24)$ and $P$. pubescens $(2 n=24)$ based on their results from pollen grain, morphological and preliminary cytological studies. In addition, they observed that $P$. angulata has a wider latitudinal range of distribution with usually large populations, which is a characteristic of the distribution of successful hybrid genomes (Olorode $e t$ al., 2013).

There is no report on artificial hybridization among Nigerian Physalis so far, hence this study. The objective of the study was therefore to carry out hybridization among the four Nigerian Physalis species to elucidate the phylogenetic relationship that exists among them.

\section{Materials and Methods}

Germplasm collection and cultivation of Physalisspecies

Whole plants of all the Physalis species studied except $P$. micrantha were collected from different locations in SouthWestern Nigeria (Table 1 and Fig. 1). Accession numbers were given to the specimens, identified at the IFE Herbarium and voucher specimens were deposited. The whole plants collected were planted and nursed to maturity. Fruits of $P$. micrantha were also collected from different locations in South-Western Nigeria. The seeds were recovered from the fruits and planted separately. The seedlings were transplanted into 11-litre plastic buckets filled with top soil, in an experimental garden field beside the screen-house of the Department of Botany, Obafemi Awolowo University, Ile-Ife, Nigeria.

\section{Hybridization}

Each of the four Physalis species was selfed before the hybridization was carried out, in order to determine their self-compatibility. Self-fertility test was carried out by randomly bagging twenty flower heads on plants of each species prior to the opening of the flowers.

Interspecific reciprocal crosses were carried out by physical emasculation of matured flower buds of each 
206

ovulate genitor before the occurrence of self-pollination. The pollen grains were transferred to the ovulate parent, bagged and labelled to prevent contamination by external pollen grains and for easy identification.

The crosses were monitored for fruit production and seed set. The $F_{1}$ hybrid from the successful cross was raised along with its genitors and characterized for all morphological differences and similarities.

\section{Meiotic chromosome study}

Young flower buds from the $F_{1}$ hybrid were collected for meiotic chromosome study between 9.00 am and 12.00 pm, when the cell activities were considered to be at the peak (Jackson, 1962) and stored in 1:3 Acetic acid:alcohol. The anthers were later removed, squashed and stained in FLP Orcein by the squash technique according to Lasebikan and Olorode (1972). The pollen cells were examined and good meiotic chromosome spreads were photographed at x1000 under BK series system microscope. The pollen stainability was carried out according to the method of Olorode and Baquar (1976) using Cotton Blue in Lactophenol.

Table 1. Germplasm sources used for the study

\begin{tabular}{|c|c|c|}
\hline Accession No. & Location & Longitudes and Latitudes \\
\hline PMR 1201 & $\begin{array}{l}\text { Open place isolated in fallowed farmland at the University of } \\
\text { Abuja Permanent site, FCT, Abuja. }\end{array}$ & $8^{\circ} 57^{\prime} 24.21^{\prime \prime} \mathrm{N} 7^{\circ} 04^{\prime} 30.56^{\prime \prime} \mathrm{E}$ \\
\hline PMR 1202 & $\begin{array}{l}\text { Dump site at Odoje Ojubo on Ogbomoso-Ajawa Road, } \\
\text { Ogbomosho, Oyo State. }\end{array}$ & $8^{\circ} 08^{\prime} 00.00^{\prime \prime} \mathrm{N} 4^{\circ} 15^{\prime} 00.00^{\prime \prime} \mathrm{E}$ \\
\hline PMR 1301 & Along the road at Omuo-Ekiti, Ekiti State. & $7^{\circ} 45^{\prime} 46.85^{\prime \prime} \mathrm{N} 5^{\circ} 43^{\prime} 28.98^{\prime \prime} \mathrm{E}$ \\
\hline PMR 1401 & Fallow land at the New Market, OAU, Ile-Ife & $7^{\circ} 29^{\prime} 12.07^{\prime \prime} \mathrm{N} 4^{\circ} 29^{\prime} 35.42^{\prime \prime} \mathrm{E}$ \\
\hline PMR 1402 & Along Road 7, Ile-Ife & $7^{\circ} 29^{\prime} 12.07^{\prime \prime} \mathrm{N} 4^{\circ} 29^{\prime} 35.42^{\prime \prime} \mathrm{E}$ \\
\hline PAG 1302 & Dump site around Pottery Museum, Moore, Ile-Ife & $7^{\circ} 35^{\prime} 25.84^{\prime \prime} \mathrm{N} 4^{\circ} 44^{\prime} 00.81^{\prime \prime} \mathrm{E}$ \\
\hline PAG 1203 & Fallow land around Music Department, OAU, Ile-Ife & $7^{\circ} 29^{\prime} 12.07^{\prime \prime} \mathrm{N} 4^{\circ} 29^{\prime} 35.42^{\prime \prime} \mathrm{E}$ \\
\hline PAG 1204 & Along the road at Oranfe area, Ile-Ife & 7o $35^{\prime} 25.84^{\prime \prime} \mathrm{N} 4^{\circ} 44^{\prime} 00.81^{\prime \prime} \mathrm{E}$ \\
\hline PPR 1205 & Dump site around, Town Hall, Iloko-Ijesa & 70 39’08.48”N 4²9'24.78”E \\
\hline PPR 1206 & Fallow land around Pottery Museum, Moore, Ile-Ife & $7^{\circ} 3525.844^{\prime \prime N} 4^{\circ} 44^{\prime} 00.81 " \mathrm{E}$ \\
\hline PPR1303 & Dump site at Akinyele LGA, Ibadan & $7^{\circ} 31^{\prime} 49.87^{\prime \prime} \mathrm{N} 3{ }^{\circ} 5439.20$ ”E \\
\hline РPB 1207 & Around Music Department, OAU, Ile-Ife & $7^{\circ} 29^{\prime} 12.07^{\prime \prime} \mathrm{N} 4^{\circ} 29^{\prime} 35.42^{\prime \prime} \mathrm{E}$ \\
\hline PPB 1208 & Dump site around Pottery Museum, Moore, Ile-Ife & $7^{\circ} 35^{\prime} 25.84^{\prime \prime} \mathrm{N} 4^{\circ} 44^{\prime} 00.81^{\prime \prime} \mathrm{E}$ \\
\hline PPB 1304 & Dump site at Akinyele LGA, Ibadan & $7^{\circ} 31^{\prime} 49.87^{\prime \prime} \mathrm{N} \mathrm{3} 3^{\circ} 5439.20$ ”E \\
\hline
\end{tabular}

${ }^{*}$ PAG- Physalis angulata; PPR- Physalis peruviana; PPB- Physalis pubescens; PMC- Physalis micrantha
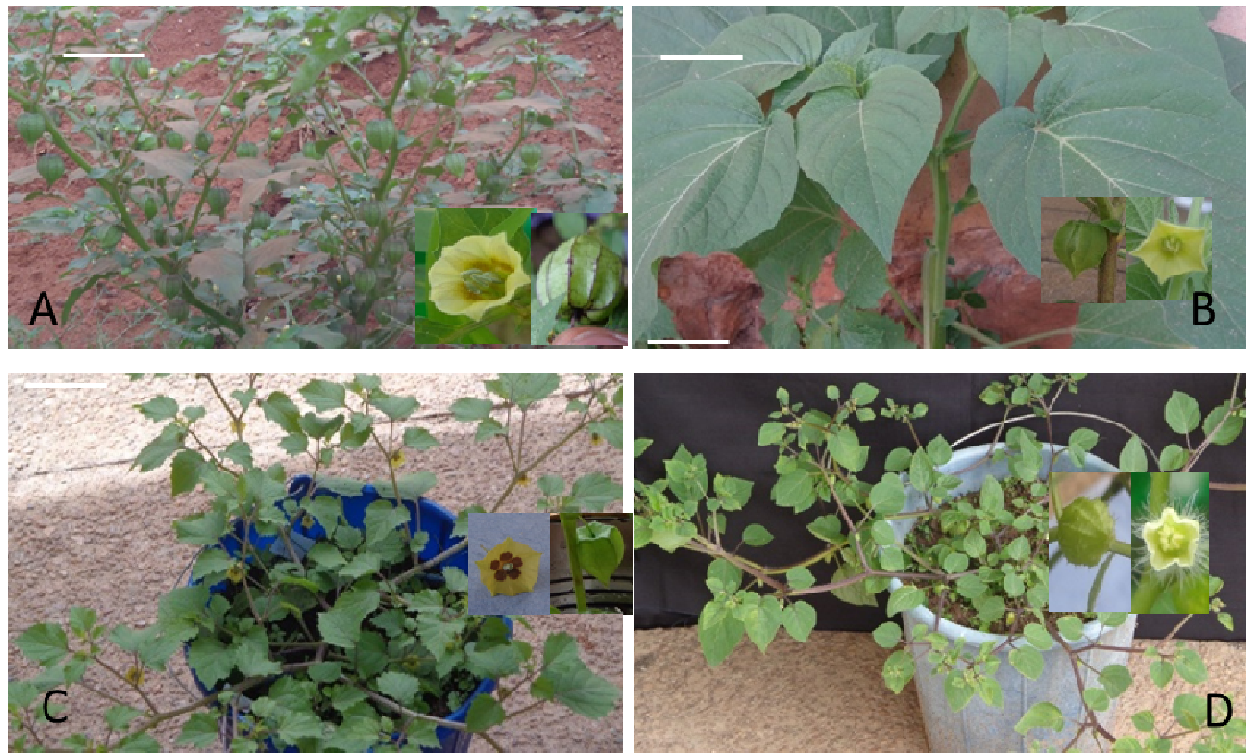

Fig. 1. Habits of Physalis species studied A. P. angulata (inset right is flower and fruit); Scale $=10 \mathrm{~cm}$; B. P. peruviana (inset right is flower and fruit); Scale $=3 \mathrm{~cm}$; C. P. pubescens (inset right is flower and fruit); Scale $=10 \mathrm{~cm}$; D. P. micrantha (inset right is flower and fruit); Scale $=5 \mathrm{~cm}$ 


\section{Results}

All the four species studied were self-compatible. No natural hybrid was observed where $P$. angulata, $P$. pubescens and $P$. peruviana were growing sympatrically, whereas $P$. micrantha was observed to be growing allopatrically in ruderal and waste places. Of all the crosses that were carried out, including the reciprocal crosses (Table 2 and 3), no successful hybrid combination was obtained, except in one cross between $P$. angulata and $P$. pubescens (Fig. 2). Most of the fertilized ovaries were aborted few weeks after fertilization. Some fruiting calyces were enlarged with immature fruits which occasionally contained aborted seeds. A few full-sized seeds which failed to germinate were recovered in some fruits.

Some matured fruits with full-sized seeds were harvested. These seeds germinated; however, the $F_{1}$ hybrid plants showed no influence of pollen donor. From $P$. angulata $\times P$. pubescens (tetraploid $x$ diploid), 15 seeds were recovered and all germinated. However, only one plant showed hybrid characteristics. Few flower buds were developed on this $F_{1}$ hybrid plant and no matured fruit was harvested.

The pollen diameter of the hybrid plant (25.40-30.72 $\mu \mathrm{m})$ fell within the range of that of the two genitors. The percentage pollen stainability of the $F_{1}$ hybrid plant was $43.25 \%$ which was about $50 \%$ less than that of the parents. The flower colour, as well as the flower orientation, took after the staminate parent (Table 4).

The pollen cells of the $F_{1}$ hybrid plant were characterized by meiotic irregularities (Fig. 3). The $\mathrm{F}_{1}$ hybrid plant was a triploid, having chromosome number of $2 n=36$. The chromosomes were unequally distributed to the two poles at anaphase I; precocious chromosome movement and multiple laggards were observed at anaphase I and II. Unpaired chromosomes were also observed in some pollen mother cells.

Table 2. The crosses involving the four Physalis species studied, including the reciprocal crosses

\begin{tabular}{|c|c|c|c|c|}
\hline & P.peruviana & P.pubescens & P. angulata & P. micrantha \\
\hline P.peruviana & - & $x$ & $x$ & $x$ \\
\hline P.pubescens & $x$ & - & $x$ & $x$ \\
\hline P. angulata & $x$ & $x$ & - & $x$ \\
\hline P. micrantha & $x$ & $x$ & $x$ & - \\
\hline
\end{tabular}

Table 3. The summary of the crosses in relation to the percentage of fertilized ovules and fruit set

\begin{tabular}{|c|c|c|}
\hline Crosses & \% Fertilized ovules & $\%$ Fruit set \\
\hline P. peruviana $x$ P. pubescens & 28.9 & 21.1 \\
\hline P. peruviana $\times$ P. angulata & 15.2 & 9.1 \\
\hline P. peruviana $\times$ P. micrantha & - & - \\
\hline P. pubescens $\times$ P. peruviana & 37.8 & 36.5 \\
\hline$P$. pubescens $x P$. angulata & 18.0 & 18.0 \\
\hline P. pubescens $x$ P. micrantha & 9.1 & - \\
\hline P. angulata $x$ P. peruviana & 14.1 & - \\
\hline P. angulata $x$ P. pubescens & 17.8 & 6.7 \\
\hline P. angulata $x$ P. micrantha & - & - \\
\hline P. micrantha $x$ P. perwviana & 35.7 & 21.4 \\
\hline P. micrantha $x$ P. pubescens & 24.0 & - \\
\hline P. micrantha $x$ P. angulata & 22.7 & - \\
\hline
\end{tabular}

Table 4. Characteristics of the $F_{1}$ hybrid plants and its genitors

\begin{tabular}{|c|c|c|c|}
\hline Species $\backslash$ Characters & P. angulata & P.pubescens & $\mathrm{F}_{1}$ hybrid \\
\hline Colour of corolla & cream with inner brown patches & yellow with inner brown patches & light-yellow with inner brown patches \\
\hline Fruiting calyx pigmentation & $\begin{array}{l}\text { pigmented along the veins on the fruiting } \\
\text { calyx }\end{array}$ & no pigmentation & pigmented along the veins on the fruiting calyx \\
\hline Leaf Venation & cladodromous & eucamptodromous & cladodromous \\
\hline Leaf Texture & glabrous & coriacious & coriacious \\
\hline Calyx Angles & 10 & 5 & 10 \\
\hline Corolla Diameter (mm) & 13.35 & 9.00 & 10.00 \\
\hline Leaf Area $\left(\mathrm{cm}^{2}\right)($ Mean $\pm \mathrm{SE})$ & $19.30 \pm 2.01$ & $15.64 \pm 1.32$ & $38.09 \pm 9.51$ \\
\hline Petiole Length $(\mathrm{cm})($ Mean \pm SE) & $4.53 \pm 0.47$ & $3.40 \pm 0.25$ & $6.30 \pm 0.63$ \\
\hline No. of secondary branches & 21.00 & 32.00 & 28.00 \\
\hline No. of primary branches & 2.00 & 6.00 & 2.00 \\
\hline Plant Height (cm) & 68.30 & 48.08 & 45.00 \\
\hline $\begin{array}{l}\text { Days to flower initiation after } \\
\text { planting }\end{array}$ & $44-46$ & 39 & 40 \\
\hline $\begin{array}{l}\text { Days spent to complete life cycle } \\
\text { after planting* }\end{array}$ & 117 & 114 & 102 \\
\hline Pollen stainability & 89.3 & 89.6 & 43.3 \\
\hline
\end{tabular}




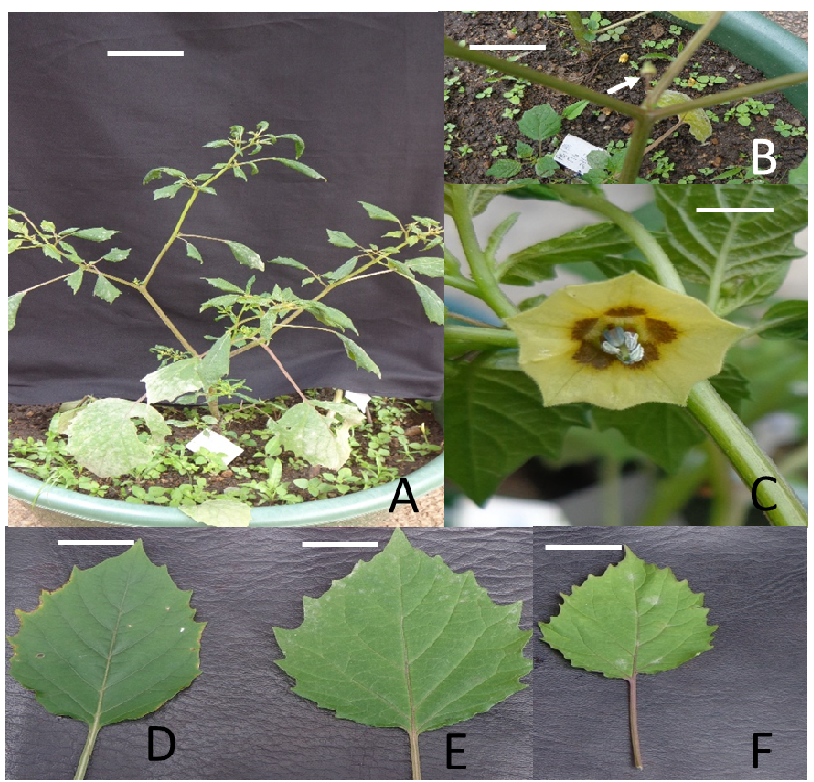

Fig. 2. $\mathrm{F}_{1}$ Hybrid between $P$. angulata $\mathrm{x} P$. pubescens $\mathrm{A}$. The habit of the $\mathrm{F}_{1}$ hybrid plant $(\mathrm{Scale}=8 \mathrm{~cm}) ; \mathrm{B}$. Fertilized ovary which slightly enlarged and later dropped after few days (arrowed) $(S c a l e=3 \mathrm{~cm})$; C. Flower of the hybrid plant $(S c a l e=0.25 \mathrm{~cm})$; D. Leaf of $P$. angulata; E. Leaf of $F_{1}$ hybrid plant; F. Leaf of $P$. pubescens (all Scale $=2 \mathrm{~cm}$ )

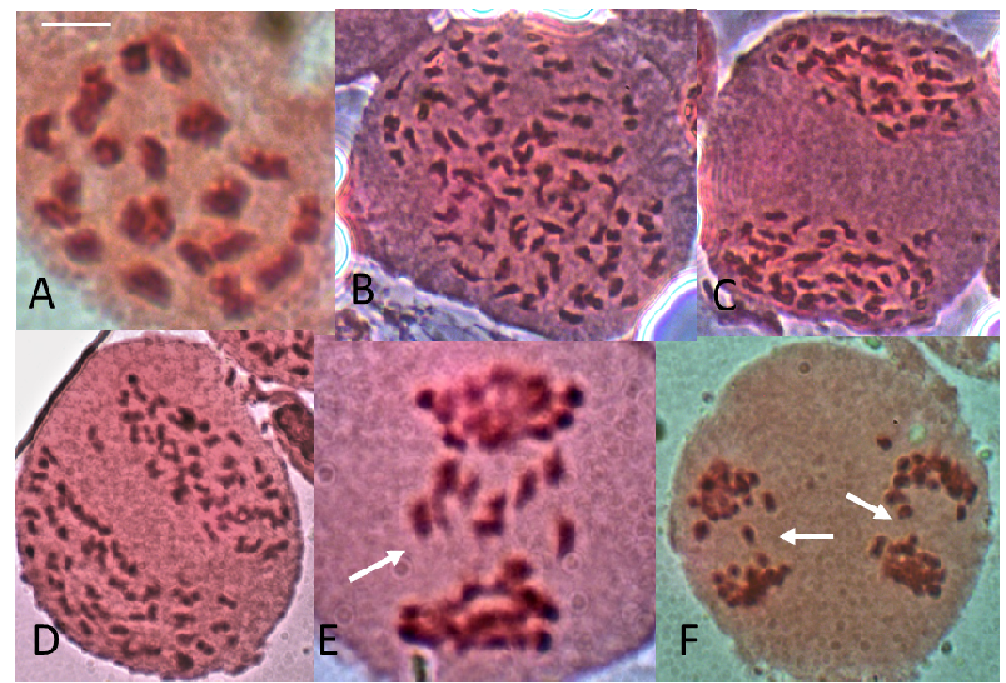

Fig. 3. Stages of cell division in P. angulata x P. pubescens F1 hybrid (Scale = $1.8 \mu \mathrm{m}$ ); A. Metaphase I (showing 18 II); B. Complete univalent (36 I) in metaphase II; C. Unpaired chromosomes in anaphase I (no laggard); D. Unequal distribution of chromosome in anaphase I (the pole at the bottom has more chromosomes than at the one at the top); E. Multiple laggards in anaphase I (arrowed); F. Laggard chromosomes in anaphase II

\section{Discussion}

It was observed from the present study that the species that were found growing sympatrically produced no natural hybrids. The lack of hybrids among closely-related sympatrically-distributed species showed that strong preand post-zygotic isolated mechanism has developed among these species and therefore prevented hybridization (Pringle and Murry, 1991; Pascarella, 2007). Fourteen out of fifteen seeds recovered from $P$. angulata and $P$. pubescens that germinated did not show the influence of pollen donor. Menzel (1951) obtained no hybrid with $P$. angulata as a seed parent and also reported that no species combination resulted in both matroclinal and hybrid populations they investigated, which was in contrast to what was observed in the $\mathrm{F}_{1}$ hybrid plants of $P$. angulata $x P$. pubescens in the present study.

In most crosses, heavy flower drop, early ovary abortion where fruiting calyces were slightly enlarged with or without ovary enlargement, as well as numerous aborted and few full-sized seeds, which failed to germinate, were observed. The unsuccessful hybridization recorded in the present study is similar to the report of Menzel (1951). Ganapathi et al. (1991) also recorded unsuccessful hybridization between $P$. pubescens and $P$. peruviana, and between $P$. pubescens and $P$. angulata including their reciprocal crosses. 
Such a result can be attributed to the fact that these species belong to different sections; even intrasectional crosses were sometimes difficult, as it was observed between $P$. pubescens and $P$. micrantha in the present study. The difficulties encountered over these crosses might also be due to the well-established barriers to hybridization in annuals (Menzel, 1951).

The embryo abortion observed in the study might be as a result of early nutrition barrier reported by Geerts $e t$ al. (2002) in the crosses between Phaseolus vulgaris and Phaseolus polyanthus. Moreover, the lack of coordination in endosperm may result in imbalanced production of growthrelating substances which in turn cause embryo abortion (Abbo and Ladizinsky, 1994). On the other hand, there might be incompatibilities between the parental genomes at cellular level which might have distorted the normal nuclear and cellular activities in the hybrid cell. Also, the parental genome may not function properly within the maternal cytoplasm (Pringle and Murry, 1991).

From the current study, one of the pollen mother cells of the hybrid obtained from the cross between $P$. angulata and $P$. pubescens showed 18 bivalents, which was a rare event. This association can be explained by the fact that $P$. pubescens designated "BB" was probably one of the genitors of $P$. angulata designated "AB" (Olorode et al., 2013). The hybrid might have undergone chromosome doubling resulting in $\mathrm{AABB}$, restoring its fertility. Perhaps the restoration of fertility in $P$. angulata by polyploidization gave rise to regular segregation that was seen in $P$. angulata. By this same reasoning, the hybrid between $P$. angulata and $P$. pubescens was $\mathrm{ABB}$. The two genitors shared similar genome, B known as pivotal genome (Kimber and Yen, 1988). Therefore, the homologous chromosomes in the $\mathrm{B}$ genome would have been able to pair, giving rise to 12 bivalents. The disruption in the meiotic mechanism governing bivalent pairing enabled the chromosomes of $\mathrm{A}$ genome to pair autosyndetically, producing 6 bivalents on a bascic number of $x=6$. This is supported by the idea of Stebbins (1971) saying that the basic chromosome number of 12 and above in some genera and families might have evolved through chromosome doubling from groups with lower numbers.

The irregularities observed in the course of meiosis in the pollen cells of the $F_{1}$ hybrid must have been responsible for malformation observed in some of the pollen grains, as well as the low pollen stainability recorded in the $\mathrm{F}_{1}$ hybrid plant. The $F_{1}$ hybrid plant obtained from the present study failed to set fruit. This was similar to the observation of Oziegbe and Faluyi (2011) in a hybrid obtained from tetraploid and diploid crosses in Ludwigia. This observation was attributed to genetically imbalanced gametes that originated from the parents of the $F_{1}$ hybrid which eventually led to hybrid sterility observed (Oziegbe and Faluyi, 2011).

\section{Conclusions}

It can be concluded from the persent study that $P$. pubescens is closely related to $P$. angulata and $P$. peruviana, while $P$. micrantha is more distant from them. This is because $P$. pubescens was able to cross reciprocally with both $P$. angulata and $P$. peruviana even though fruits were not set, except in the cross between $P$. angulata and $P$. pubescens.

\section{References}

Abbo S, Ladizinsky G (1994). Genetic aspects of hybrid embryo abortion in the genus Lens L. Heredity 72(2):193-200.

El-Sheikha AF, Ribeyre F, Larroque M, Reynes M, Mentet D (2009). Quality of Physalis (Physalis pubescens L.) juice parkaged in glass bottles and flexible laminated packs during storage at $5^{\circ} \mathrm{C}$. African Journal of Food, Agriculture, Nutrition and Development 9(6):1389-1405.

Ganapathi A, Sudhakaran S, Kulothungan S (1991). The diploid taxon in Indian natural populations of Physalis $\mathrm{L}$. and its taxonomic significance. Cytologia 56:283-288.

Geerts P, Taussaint A, Mergeal G, Baudoin J-P (2002). Study of early abortion in reciprocal crosses between Phaseolusvulgaris $\mathrm{L}$. and Phaseolus polyanthus Greenm. Biotechnologie, Agronomie, Society and Environment 6(2):109-119.

Hutchinson J, Dalziel JM (1963). Flora of West Tropical Africa 11: 329. White Fnar Press, London. Revised by Crown Agents, London.

Jackson RC (1962). Interspecific hybridization in Haplopappus and its bearing on chromosome evolution in Blepharodon section. American Journal of Botany 49(2): 119-132.

Jagatheeswari D (2014). Morphological studies on flowering plants (Solanaceae). International Letters of Natural Sciences 10:36-43.

Kimber G, Yen Y (1988). Analysis of pivotal-differential evolutionary patterns. Proceedings of the National Academy of Sciences 85(23): 9106-9108

Lasebikan AB, Olorode O (1972). Morphological variation and cytological aberrations in the natural population of Zonocerus variegatus $\mathrm{L}$. (Orthoptera: Pyrgomorphidae). The Bulletin of the Entomology Society of Nigeria 3:127-133.

Menzel MY (1951). The cytotaxonomy and genetics of Physalis. Proceedings of the American Philosophical Society 95(2):132-183.

Olatunji OA (1985). The taxonomy of Physalis Linn. (Solanaceae) in Nigeria. Nigerian Journal of Sciences 19(1-2):20-25.

Olorode O (1984). Taxonomy of West African flowering plants. First Published by Longman Group Limited. ISBN 978-978-9046546.

Olorode O, Barquar SR (1976). The Hyparrhenia involucrate-H. Subplumosa (Gramineae) complex in Nigeria. Morphological and cytological characterization. Botanical Joournal of the Linnean Society 72(3):212-222

Olorode O, Olayanju S, Garba A (2013). Physalis (Solanaceae) in Nigeria. Ife Journal ofScience 15(1):101-109.

Oziegbe M, Faluyi JO (2011). Interspecific hybridization of Ludwigia abyssinica A. Rich. with Ludwigia decurrens Walter, $L$. erecta (Linn.) Hara, L. hyssopifolia (G.Don.) Excell and L. leptocarpa (Nutt.) Hara. Nigerian Journal of Genetics 25:78-85.

Pascarella JB (2007). Mechanism of prezygotic reproductive isolation between two sympatric species, Gelsemium rankinii and Gelsemium 
sempervirens (Gelsemiaceae) in the Southern Eastern United States. American Journal of Botany 94(3): 468-476.

Pringle GJ, Murry BG (1991). Interspecific hybridization involving the tamarillo, Cyphomandra betacea (Cav.) Sendt. (Solanaceae). New Zealand Journal ofCrop Horticultural Science 19(2):103-111.

Shu SJ (1994). Physalis Linn. Flora of China 17: 311-312. Beijing: Science Press and St Louis: Missouri Botanical Garden.

Stebbins GL (1971). Chromosomal evolution in higher plants. London, Edward Arnold, pp 72-123.

Sullivan JR (1984). Systematic studies in Physalis (Solanaceae). University of Oklahoma, pp 262.

Sultana N, Hassan MA, Bejin M, Sultana M (2008). Physalis angulata L. (Solanaceae) - A new angiospermic record for Bangladesh. Bangladesh Journal of Botany 37(2):195-198. 